\title{
Environmental Regulation and the Spatial Distribution of Capital and Resources
}

\author{
Ted W. Chiles, Jr. and Joy Clark*
}

Abstract: This paper explores the impact of the Endangered Species Act on the profits of firms in the paper and pulp industries. In 1989, the federal courts enjoined timber-cutting contracts in old-growth forest areas that might contain northern spotted owl. This action was perceived to decrease substantially the profits of firms with a high spatial concentration of mills in the Northwest. The empirical evidence does not support this hypothesis. These same firms are shown to benefit from the environmental regulation because the value of privately held timber increased in the Northwest.

\section{INTRODUCTION}

The sale of old-growth timber in U.S. National Forest lands in the Pacific Northwest came to a virtual standstill in the spring of 1989. Responding to arguments in a suit brought under the Endangered Species Act, a federal judge enjoined the U.S. Forest Service from awarding timber cutting contracts in oldgrowth forest areas that might contain northern spotted owl (Strix occidentalis caurina). This reduced the supply of government timber that pulp and paper companies in the northwestern United States had available to harvest and raised the cost associated with obtaining the fiber needed to make paper (Longview Fibre Company 1994).

This paper explores the impact of this environmental regulation on the profits of firms in the paper and pulp industries. The model to be analyzed and tested is a reduced-form profit equation that uses the percentage of government timber out of total timber supply as a cost-shifter. The paper argues that since government land is subject to greater environmental regulation than private land, regulation will increase the cost of timber extracted from government land. The greater the reliance on government timber the greater the potential decrease in profits, ceteris paribus. It is expected that the companies that have a greater number of their plants located in the Northwest suffered more from this regulation than the companies with firms concentrated in other areas of the country.

A second hypothesis is that the value of privately held timber will increase with the enforcement of environmental regulation since the vertically integrated paper and pulp firm could capture a share of rents generated by the environmental regulation. If the net gain in the asset value of timber holdings is greater than the loss associated with higher input (timber) prices, the regulation could have a net positive impact for the paper and pulp firm. In this case, paper and pulp firms that are not vertically integrated will face higher input prices and have

*Associate Professors of Economics, Auburn University Montgomery, Montgomery, AL. 
lower profits. The impact on profitability is therefore a function of the vertical integration of the firm and its holdings of private timber lands.

Wood fiber is the basic ingredient for paper production and up to one-half of the fiber needed is attained through trees cut specifically for the purpose of making paper. The remaining fiber used in paper production comes from recycled material and waste particles. Our analysis differs from the previous studies of this controversy in that it focuses on the profitability of the paper and pulp firm rather than on the profitability of the timber stand. Timber is viewed as an input in this analysis. As a result of the northern spotted owl regulation, timber-using industries will incur differing levels of increased costs. The degree of change will be dependent on the location of their production facilities and the sensitivity of costs to timber prices.

\section{PREVIOUS STUDIES}

The literature dealing with the forest industry and the spotted owl has two distinct areas of work: studies dealing with the successful management of the forest resource in the face of government policy changes and other studies concerned with the preservation value of the spotted owl. Very little of the economic literature appears to consider the impact upon the pulp and paper industry of this legislation and in particular the geographical differences in the impact upon these industries. Most of the work appears to be anecdotal in nature.

One recent paper by Murray and Wear (1998) examines the extent to which the northern spotted owl legislation and the resulting restrictions on timber available for processing may have altered the degree of integration between the Pacific Northwest and the U.S. South in the national market for timber. Their analysis of monthly price data suggests that a structural break occurred in the relationship between the two regions' product prices around the time of the harvest restrictions. This structural break lead to a more integrated market after the restrictions were imposed.

Appropriate management strategies for the forest resource were addressed in papers by Berck (1981), Merrifield and Hayes (1984), and Clawson (1977). These researchers examined the unique strategies that must be considered for a resource with a growing demand and constraints to decision making that run the gamut from biological to public policy. A large amount of the literature that deals with the appropriate use of the forest resource focuses on the difficulty of establishing a value for the resource that reflects the multiuse nature of forests (Hartman 1976; Bowes and Krutilla 1989). This issue is further complicated by government policy that, through the allocation of rights to public lands and inefficient pricing strategies, ensures that there will be price differentials between private and public forest reserves (Bowes and Krutilla 1989). The result of these price differentials will be to make public forests less expensive than their private counterparts. The implication of the price differential is an initial geographical bias towards the Northwest region due to its extensive and advantageously priced public reserves. 
The value of the spotted owl was examined in a paper by Rubin, Helfand, and Loomis (1991), in which a benefit-cost analysis was conducted. Montgomery and Brown (1992) attempted to build a supply curve for survival of the northern spotted owl and to use this to estimate the welfare impacts of timber harvest reductions upon the spotted owl. The supply curve related the probability of northern spotted owl survival to the present value to consumer and producers of foregone timber harvest over time. A national contingent valuation study of the benefits of preserving old-growth forests and the spotted owl found that estimated benefits exceeded the cost of the conservation policy across all policy scenarios examined (Hagen, Vincent, and Welle 1992).

\section{POTENTIAL IMPACT OF ENVIRONMENTAL REGULATION}

The basic theory of the firm suggests that as the relative price of an input rises the firm's cost of production will rise. Should this rise in input price be spatially distributed, all other things being equal, firms located in the high input price area will be at a competitive disadvantage to those firms located in the low input price area in the short run. Previous research by Chiles, Clark, and Fulford (1998) examining the differential impact of location on the firm's profits provides weak support for a negative impact from the spotted owl injunction. This paper reformulates the simple competitive model by introducing the additional influences of union status and regulatory rents.

It is of particular interest that the timber firms located in the northwestern United States have historically been at a competitive advantage in paper and pulp production because of the access to federal lands. The pricing strategy for federal lands is such that this timber was "less expensive" than the private counterparts. This competitive advantage can be considered a first mover advantage for the firms originally located in the area and any differential profits would be quasi-rents.

The condition necessary for the long-run existence of a unionized firm is some form of appropriable rent. Unionized workers receive higher wages than nonunion workers in similar jobs. Empirical evidence suggests that these wages are not usually compensating wage differentials. ${ }^{1}$ The existence of higher wages indicates higher costs and, hence, places the unionized firm at a competitive disadvantage. The unionized firm can coexist only if some form of rent is the source of the union wage premium. For example, two firms with differing costs can coexist in an oligopoly when further entry is precluded. The barriers to entry are the source of the rent. Other sources of appropriable rents are any specific asset or an asset with greater value in use than exchange.

The quasi-rents associated with the first mover advantage of locating in the Northwest initially may have attracted unions to these firms. However, the positive source of quasi-rents (a Northwest location) has been transformed into

${ }^{1}$ Mitchell and Stone (1992) find lower productivity in union sawmills. The potential for a positive gain in efficiency with union status is contradictory to the large body of evidence of the negative impact of union status on profits. See Addíson and Hirsch (1989) for a review. 
a potential cost disadvantage because of the increased environmental regulation. ${ }^{2}$ Consider the management discussion of labor costs in Longview Fibre Company's Fiscal Year 1993 10-K report: "Labor costs in the Pacific Northwest paper industry were bargained to very high levels when the region had low chip costs and could afford wages substantially above typical manufacturing rates. But with the reduction of government timber sales, chip costs in the region are now around twothirds higher than those of the South. The premium wage rates are now a severe penalty" (Longview Fibre Company 1994, p. 8).

If timberlands are an appropriable asset we would expect unionization of timber-producing and timber-using companies. Given the union status of the firm as a preexisting condition, then the transferability of the asset at full value is questionable. Timberlands are site specific assets. As a result, a nonunion buyer will discount the value of the timberland located in a union environment. The greater this discount in value, the greater the difference between value in use and value in exchange. This difference is the bargaining range. For any given level of bargaining power, the union's share of the range is constant. Therefore, as the size of the bargaining range increases, assuming employment is constant, the per worker share or union wage premium will rise. The increases in chip prices combined with the large union wage premiums in the West have placed the unionized firms at a severe disadvantage.

Several timber-using firms are also timber producers. These vertically integrated firms will differ from strictly horizontal firms. Given that timber has relatively high transportation costs, as noted in Murray and Wear (1998), the timber assets located in the Northwest will increase in value relative to national average price. Because pulp and paper plants and the timber supplies are site specific, the vertically integrated firm in the Northwest will benefit. The benefits of holding timberlands or leases and the potential for quasi-rents are described in Boise Cascade's Fiscal Year 1993 10-K report:

In recent years, heightened attention has been paid to developing and implementing recovery plans for U.S. species that are listed as threatened or endangered under the Endangered Species Act of 1973. Some of these plans...have sharply curtailed the amount of federal government timber available for commercial harvest. As a result, approximately 8.4 billion board feet of timber on national forests were under contract and awaiting harvest in 1994, down from 17.9 billion board feet five years earlier. Over the last few years, increased harvests from private, nonindustrial lands have partially offset the loss of timber available from federal forests in the Pacific Northwest. However, in the Company's judgment, the current rate of harvest on private, nonindustrial timberlands cannot be sustained and, at some point, will decline markedly.

In this environment, Boise Cascade has relative advantages. An important share of our raw material needs is met by our own timberland....The cost of logs delivered to our Northwest wood products

\footnotetext{
${ }^{2}$ The marbled murrelet and the Snake River salmon have been listed as threatened or endangered in the Northwest. In the Southeast, the red-cockaded woodpecker has been listed as endangered. Georgia-Pacific reached an agreement with the U.S. Fish and Wildlife Service to conserve the red-cockaded woodpecker's habitat. Georgia-Pacific can continue to extract timber.
} 
facilities climbed $74 \%$ from 1989 to 1994 , while wood chip costs for our Northwest pulp mills rose $75 \%$ from 1987 to 1991, before leveling off. Despite rapidly increasing log costs, our Northwest wood products operations have maintained stable profit margins due to use of timber from our own lands...and rising prices $^{3}$ (Boise Cascade Corporation 1994, p. 7).

Therefore, the location of the firm's production facilities in the Northwest currently has three potential effects on cost, hence profits. First, higher current input costs result because of higher chip and timber prices from external sources. Second, higher wages result from union status and traditionally lower input prices. ${ }^{4}$ Finally, the opportunity cost associated with the use of internal private timber holdings by vertically integrated firms increases.

The pulp and paper industry may also gain valuable rents from the decreased supply of government timber. The value of existing assets was increased by the restrictions on the harvest of government timber. As a result, these environmental restrictions have the potential to generate valuable rents, some of which can be captured by the regulated firms. Evidence of the ability to capture regulatory rents is demonstrated in Maloney and McCormick (1982) for smelting firms. The recent increase in timber and chip prices could also have generated a profitable outcome for some of the firms located in the other regions.

\section{EMPIRICAL MODEL AND DATA}

The empirical analysis employs a reduced-form model of firm's profits that is estimated using a cross section of firms in the Paper and Allied Products Industry (SIC 26) and the Lumber and Wood Products Industry (SIC 24), as designated in each firm's $10-\mathrm{K}$ report. ${ }^{5}$ The use of a reduced-form profit model is driven by two considerations. First, the conceptual model is based on a general rent-seeking model. The rent-seeking model simply requires the existence of quasi-rents. The model is not based on a particular belief of the level of market power, heterogeneity of products, or relative efficiency of firms. Second, data constraints prevent the estimation of a flexible functional-form profit function such as a translog. Even with the firm-specific information in a $10-\mathrm{K}$ report, input prices are not usually available.

The two primary variables of interest in our model are the firm location variable (measured by PULPLOC, PAPERLOC, and PRCONV, as defined in Table 1) and the timber location variable (measured by TIMLOC, as defined in Table 1).

\footnotetext{
${ }^{3}$ The opportunity cost of the use of the timberland has also increased; therefore the firm is spending the windfall internally.

${ }^{4}$ First, the initial cost advantage of the Northwest firms could have been used strategically with the union. Two of the earliest articles in the raising rival costs literature focused on the use of union wages as the cost-increasing mechanism. Williamson's (1968) analysis of the Pennington case demonstrates that the minimum wage standard in government coal contracts acted as a barrier to entry for nonunion (labor-intensive) firms. In Maloney, McCormick, and Tollison (1979), unions are shown to have the potential to act as a cartelizing agent for the firms by reducing output. Union status is present in all regions. The increase in Northwest wages could have translated into wage increases in other regions, if pattern bargaining existed. The higher cost could lead to a competitive advantage for the Northwest firm.

5 The firm's industry designation is determined by the line of business with the highest percentage of sales.
} 
Both variables capture the geographic dispersion of each firm. Total profit for firm i can be expressed as:

$$
\pi_{\mathrm{i}}=\alpha \pi_{\mathrm{nw}}+(1-\alpha) \pi_{\mathrm{other}},
$$

where $\pi_{\mathrm{i}}$ is total profits, $\pi_{\mathrm{NW}}$ is profits of the firm's Northwest holdings, $\pi_{\text {other }}$ is the profit of the firm's holdings outside the Northwest, and a is the percentage of the firm's holdings in the Northwest. The three plant location variables approximate $\alpha$. The expectation is that, after 1989, the greater $\alpha$, the lower the firm's profits.

It is hypothesized that $\pi_{\mathrm{NW}}$ is less than $\pi_{\text {other }}$ because of the regional differences in the price of timber. Before 1989, the price of timber in the Northwest $\left(\mathrm{P}_{\mathrm{nw}}\right)$ was:

$$
\mathrm{P}_{\mathrm{nw}}=\gamma \mathrm{P}_{\text {gov }}+(1-\gamma) \mathrm{P}_{\text {private }}
$$

where $\gamma$ is the ratio of government timber to total timber supplied and $P_{\text {gov }}$ and $P_{\text {private }}$ are the prices of government and privately supplied timber, respectively. In $1989 \gamma$ significantly decreased; therefore if $P_{\text {private }}>P_{\text {gov }}$, then $P_{n w}$ rose.

The basic reduced-form profit equation is

$$
\begin{aligned}
& \text { RSALES }_{\mathrm{i}}=\mathrm{a}_{0}+\mathrm{a}_{1} \mathrm{KI}_{\mathrm{i}}+\mathrm{a}_{2} \mathrm{TI}_{\mathrm{i}}+\mathrm{a}_{3} \text { TIMLOC }_{\mathrm{i}}+\mathrm{a}_{4} \mathrm{UNDV}_{\mathrm{i}}+\mathrm{a}_{5} \mathrm{LOC}_{\mathrm{i}}+\mathrm{a}_{6} \text { PULP } \\
& +\mathrm{a}_{7} \text { PAPER }+\mathrm{a}_{8} \text { CONV }+\mathrm{e}_{\mathrm{i}},
\end{aligned}
$$

where RSALES is returns to sales. Returns to sales is a short-run profit measure that is closely related to a price-cost margin. However, the returns to sales measure differs from a price-cost margin with the deduction of capital costs and depreciation. $\mathrm{KI}$ is capital intensity and captures the firm's expenditures on property, plant, and equipment except for timber holdings. TI is a measure of the firm's timber holdings divided by sales. UNDV is a dummy variable that controls for the union status of the firm. PULP, PAPER, and CONV are equal to 1 if the firm operates a plant in the pulp, paper, or converted paper segment. All of the nominal variables are equalized by sales. ${ }^{6}$ The variables' definitions and data sources are found in Table 1.

Two variables were developed to represent the impact of the spotted owl policy upon the firms. One variable represented the plant location and the other the location of timber holdings. The plant location variable or spatial capital variable, LOC, has three possible measures. A firm can operate a pulp, paper, and/or converted paper mill in the Northwest. Using the Lockwood-Post's directory of the pulp, paper and allied trades $(1993,1994)$, three different location variables were constructed. Capacity variables were constructed for pulp and paper mills. LOCPULP is the percentage of the firm's Northwest pulp production capacity out of total pulp production capacity. LOCPAPER is the same for the firm's paper production capacity. The data available on converted paper plants did not contain

${ }^{6}$ It is appropriate to use sales as the equalizing weight when price-cost margins are measured as returns to sales. The other nominal values must also be weighted to capture the relative impact on profitability of an expenditure. If actual expenditures were used on a weighted profit measure, then the per dollar impact would be biased inversely with the size of the firm. 
capacity measures. We simply calculated the percentage of converted paper plants located in the Northwest. This location variable was designated PRCONV. The expected sign of the plant location variable is negative.

TABLE 1

Definitions of Variables

\begin{tabular}{|c|c|}
\hline RSALES & Returns to sales measured as accounting profit plus interest expense divided by sales. \\
\hline KI & $\begin{array}{l}\text { Capital intensity measured as gross book value of property, plant, and equipment less } \\
\text { timber holding divided by sales. }\end{array}$ \\
\hline TI & Timber holdings divided by sales. \\
\hline TIMLOC & $\begin{array}{l}\text { Percentage of timber reserves located in the Northwest out of total timber reserves in } \\
\text { North America. }\end{array}$ \\
\hline UNDV & Union status dummy variable where $\mathrm{UNION}=1$ if union, $\mathrm{UNION}=0$ if non-union. \\
\hline LOCPULP & $\begin{array}{l}\text { Percentage of pulp production capacity located in the Northwest, from the Lockwood- } \\
\text { Post's directory of the pulp, paper and allied trades }(1993,1994) \text {. }\end{array}$ \\
\hline LOCPAPER & $\begin{array}{l}\text { Percentage of paper production capacity located in the Northwest, from the Lockwood- } \\
\text { Post's directory of the pulp, paper and allied trades }(1993,1994) \text {. }\end{array}$ \\
\hline PRCONV & $\begin{array}{l}\text { Number of converted paper plants located in the Northwest, from the Lockwood-Post's } \\
\text { directory of the pulp, paper and allied trades }(1993,1994) \text {. }\end{array}$ \\
\hline PULP & Production dummy variable where PULP $=1$ if firm has a pulp plant and 0 otherwise. \\
\hline PAPER & Production dummy variable where PAPER $=1$ if firm has a paper plant and 0 otherwise. \\
\hline CONV & $\begin{array}{l}\text { Production dummy variable where } C O N V=1 \text { if firm has a converted paper plant and } \\
0 \text { otherwise. }\end{array}$ \\
\hline
\end{tabular}

Source: All data from firms' Security and Exchange Commission 10-K reports unless otherwise indicated.

The TIMLOC variable is included to capture the potential effect of vertical integration into timber production on the observed profitability of the firm. The increase in the value of the timber asset can be consumed internally and the firm's observed profitability will be higher, as described in Boise Cascade Corporation (1994). This internal provision will result in the firm's own price of timber being lower than the average price in the Northwest. TIMLOC is measured as the firm's percentage of timber holdings in the northwestern portion of the country out of total timber resources in North America. The implicit assumption is that the timber resources are of equal type and quality across all locations. The expected sign of TIMLOC is positive. The effect of an increase in the value of the firm's timber holdings on economic profits would be zero since the opportunity costs of internal use would be equal to the value in external exchange. Given that the timber cost is priced at historical cost, then the expected effect is positive.

The union dummy variable, UNDV, is included to control for the difference in profitability of union and nonunion firms. The union impact may have been greater in the Northwest since union wages were historically higher because of the supply of government timber. The union status of the firm is measured as a union dummy variable. Unions are expected to have a negative impact on the profits of the firm. Ideally, we would like to isolate the actual unionization rate and its geographic dispersion. The majority of firms in this sample do not provide such specific data. The use of a union dummy variable implicitly assumes that the majority of the impact of unions on firm performance is found at low levels of unionization. If internal threat effects increase the internal nonunion wage, then 
the dummy variable approximates the unionization rate, as demonstrated in Clark (1984) and Becker and Olson (1992).

The data set is a 1993 cross section of 33 firms. While the spotted owl was not listed as an endangered species until 1990, the initial impact of the spotted owl legislation may have begun in the spring of 1989 with the proposed listing. The firms in our sample have had three years to adjust to the imposition of the environmental regulation. The 33 firms in the sample contain 23 of the top 40 pulp and/or paper firms in the United States. The firms operate 40 percent of the pulp plants and 35 percent of the paper plants in the United States.

\section{RESULTS}

Five different specifications of equation (3) are estimated using TSP with the OLS(ROBUST) option. The results are shown in Table 2. The empirical results do not support the primary hypothesis that the spotted owl injunction decreased the profits of firms located in the Northwest. The three plant location variables are all statistically insignificant. No differential impact is observed on firms with pulp, paper, and/or converting plants located in the Northwest. The impact of the spotted owl injunction has either come and gone or never happened. In contrast to Chiles, Clark, and Fulford (1998), our results suggest that the expected negative impact of the spotted owl injunction did not occur.

TABLE 2

Regressions of Location Variables on Returns to Sales for 1994

\begin{tabular}{|c|c|c|c|c|c|}
\hline Variable & 1 & 2 & 3 & 4 & 5 \\
\hline Constant & $\begin{array}{c}0.1554^{* *} \\
(0.0408)\end{array}$ & $\begin{array}{c}0.1622^{* *} \\
(0.0412)\end{array}$ & $\begin{array}{c}0.1611^{* *} \\
(0.0412)\end{array}$ & $\begin{array}{c}0.1559^{* *} \\
(0.0428)\end{array}$ & $\begin{array}{c}0.1602^{* *} \\
(0.0427)\end{array}$ \\
\hline KI & $\begin{array}{l}-0.0126 \\
(0.0183)\end{array}$ & $\begin{array}{l}-0.0146 \\
(0.0198)\end{array}$ & $\begin{array}{l}-0.0146 \\
(0.0199)\end{array}$ & $\begin{array}{l}-0.0124 \\
(0.0202)\end{array}$ & $\begin{array}{l}-0.0144 \\
(0.0198)\end{array}$ \\
\hline TI & $\begin{array}{c}0.0802 \\
(0.1329)\end{array}$ & $\begin{array}{c}0.0167 \\
(0.1241)\end{array}$ & $\begin{array}{c}0.0105 \\
(0.1241)\end{array}$ & $\begin{array}{l}-0.0027 \\
(0.1222)\end{array}$ & $\begin{array}{c}0.0116 \\
(0.1222)\end{array}$ \\
\hline TIMLOC & - & $\begin{array}{l}0.00084^{* *} \\
(0.0003)\end{array}$ & $\begin{array}{l}0.0010^{* *} \\
(0.0004)\end{array}$ & $\begin{array}{l}0.0014^{* *} \\
(0.0007)\end{array}$ & $\begin{array}{l}0.0010^{* * *} \\
(0.0004)\end{array}$ \\
\hline UNDV & $\begin{array}{l}-0.0914^{* *} \\
(0.0421)\end{array}$ & $\begin{array}{l}-0.0917^{* *} \\
(0.0403)\end{array}$ & $\begin{array}{l}-0.0914^{* *} \\
(0.0401)\end{array}$ & $\begin{array}{l}-0.0936^{* *} \\
(0.0406)\end{array}$ & $\begin{array}{l}-0.0910^{* *} \\
(0.0420)\end{array}$ \\
\hline LOCPULP & - & - & $\begin{array}{l}-0.00023 \\
(0.00037)\end{array}$ & - & - \\
\hline LOCPAPER & 一 & - & - & $\begin{array}{l}-0.0008 \\
(0.0007)\end{array}$ & - \\
\hline PRCONV & - & - & - & - & $\begin{array}{l}-0.0007 \\
(0.0014)\end{array}$ \\
\hline PULP & $\begin{array}{c}0.00023 \\
(0.0275)\end{array}$ & $\begin{array}{l}-0.0059 \\
(0.0251)\end{array}$ & $\begin{array}{l}-0.0052 \\
(0.0248)\end{array}$ & $\begin{array}{l}-0.0102 \\
(0.0241)\end{array}$ & $\begin{array}{l}-0.0070 \\
(0.0247)\end{array}$ \\
\hline PAPER & $\begin{array}{c}0.0434 \\
(0.0341)\end{array}$ & $\begin{array}{c}0.0472 \\
(0.0301)\end{array}$ & $\begin{array}{c}0.0479 \\
(0.0298)\end{array}$ & $\begin{array}{r}0.0539 * \\
(0.0309)\end{array}$ & $\begin{array}{c}0.0485 \\
(0.0316)\end{array}$ \\
\hline CONV & $\begin{array}{l}-0.0687^{* *} \\
(0.0288)\end{array}$ & $\begin{array}{l}-0.0747^{* *} \\
(0.0279)\end{array}$ & $\begin{array}{l}-0.0738^{* *} \\
(0.0278)\end{array}$ & $\begin{array}{l}-0.0695^{* *} \\
(0.0286)\end{array}$ & $\begin{array}{l}-0.0722^{* *} \\
(0.0287)\end{array}$ \\
\hline F Statistic & 2.752 & 3.109 & 2.666 & 2.813 & 2.682 \\
\hline P Value & $(0.033)$ & $(0.017)$ & $(0.030)$ & $(0.024)$ & $(0.024)$ \\
\hline Adj $R^{2}$ & 0.247 & 0.316 & 0.294 & 0.312 & 0.296 \\
\hline
\end{tabular}

*Indicates a t statistic greater than 1.70 and a $p$ value less than 0.10 .

**Indicates a t-statistic greater than 2 and a $p$ value less than 0.05 .

All standard errors are heteroskedastic-consistent. 
The empirical results do support the secondary hypotheses of the continued negative impact of unions and potential regulatory rents from the spotted owl injunction. The union variable, UNDV, is negative and significant in all specifications. The magnitude of the coefficient is robust across all specifications. The existence of a union decreases a firm's returns to sales by an average of 9 percent.

The Northwest location of timber holdings has a positive effect on firm performance. The TIMLOC variable is significant in all specifications. The coefficient is consistently positive but the magnitude does vary across specifications from a low of 0.00084 to a high of 0.0014 . This variation in the size of the coefficient suggests possible multicollinearity between the timber and plant location variables. The simple correlation coefficient between TIMLOC and the plant location variables ranges from 0.79 to 0.53 . Correlation is expected. Timber is a site specific asset and most pulp and paper plants are located near the source of their primary input.

Multicollinearity could explain the insignificance of the plant location variables. Following Greene (1997), we estimated the model with a subset of the data and compared results. The signs and significance of the TIMLOC, LOCPULP, LOCPAPER, PRCONV, and UNDV variables remained unchanged. The relative magnitudes of the coefficient of determination and F-statistic do not indicate a serious multicollinearity problem.

Neither the capital intensity nor the timber intensity variables are statistically significant. This result is surprising since previous studies, such as Chiles and Stewart (1993), found capital intensity to be not only a positive determinate of profits but also robust to different specifications. The model was also estimated including advertising, research and development intensity, and growth rate of firm sales. In no regression were any of these variables significant.

\section{CONCLUSION}

This paper predicted that companies that have a greater number of their plants or production capacity located in the Northwest would suffer more from the increases in timber prices resulting from environmental regulation than the companies with plants concentrated in other areas of the country. Given the relatively high transportation costs of timber, the timber assets located in the Northwest will increase in value relative to the average price across the market. This potential gain to timber location in the Northwest is demonstrated. Finally, the negative effect of union status is again confirmed.

The primary hypothesis of the spatial disadvantage of a Northwest location is not supported. The net impact of union status and Northwest timber holdings is uncertain. The empirical results suggest that a Northwest firm with a union and without timber holdings is at a competitive disadvantage. Timber holdings are themselves not a significant positive asset in the current environment, but Northwest timber holdings are an advantage.

The effects of overall environmental regulation on manufacturing have received substantial attention. Jaffe, Peterson, and Portney's (1995) review of the 
literature on the impact of environmental regulation on the competitiveness of U.S. manufacturing concludes that the empirical evidence only weakly supports the negative effects of environmental regulation on U.S. firms competing in global markets. This study does not find the expected negative effect. The results of this study suggest that the potential impact on a firm of decreases in the supply of an input is not unambiguously negative. If the firms are vertically integrated, then the expected negative impact should not be assumed. A spatially diversified firm may benefit from the regulation. The next step in this research program is to examine whether vertically integrated firms recognized the potential benefits of environmental regulation and indirectly supported the regulation.

\section{REFERENCES}

Addison, John T., and Barry T. Hirsch. "Union Effects on Productivity, Profits, and Growth: Has the Long Run Arrived?" Journal of Labor Economics 7 (January 1989), 72-105.

Becker, Brian E., and Craig A. Olson. "Unions and Firm Profits." Industrial Relations 31 (Fall 1992), 395-415.

Berck, P. “Optimal Management of Renewable Resources with Growing Demand and Stock Externalities." Journal of Environmental Economics and Management 8 (1981), 105-117.

Boise Cascade Corporation. Form 10-K, Commission File Number 1-5057, Fiscal Year 1993, filed March 1994.

Bowes, M.D., and J.V. Krutilla. Multiple-Use Management: The Economics of Public Forestland. Washington, D.C.: Resources for the Future, 1989.

Chiles, Ted W., and James B. Stewart. "Union Rent Appropriation and Ex Post Analysis." Journal of Labor Research 14 (3) (Summer 1993), 317-333.

Chiles, Ted W., Joy Clark, and Kirk Fulford. "That Damn Owl: Does the Spotted Owl Have a Negative Impact." Auburn University at Montgomery School of Business Working Paper 98 (13), 1998.

Clark, Kim B. "Unionization and Firm Performance: The Impact on Profits, Growth, and Productivity." American Economic Review 74 (December 1984), 893-919.

Clawson, Marion. "Decision-Making in Timber Production, Harvest, and Marketing." Resources for the Future Research Paper R-4, Washington, D.C., 1977.

Greene, William H. Econometric Analysis. 3rd ed. Upper Saddle River, NJ: Prentice Hall, 1997.

Hagen, Daniel A., James W. Vincent, and Patrick G. Welle. "Benefits of Preserving Old-Growth Forests and the Spotted Owl." Contemporary Policy Issues 10 (2) (April 1992), 13-26.

Hartman, R. "The Harvesting Decision When a Standing Forest Has Value." Economic Inquiry 14 (1976), 52-58.

Jaffe, Adam B., Steven R. Peterson, and Paul R. Portney. "Environmental Regulation and the Competitiveness of U.S. Manufacturing: What Does the Evidence Tell Us? Journal of Economic Literature 33 (March 1995), 132-163. 
Lockwood-Post's directory of the pulp, paper and allied trades. Vol. 120. San Francisco, California: Miller Freeman Publications, 1993. . Vol. 121. San Francisco, California: Miller Freeman Publications, 1994.

Longview Fibre Company. Form 10-K, Commission File Number 0-1370, Fiscal Year 1993, filed January 1994.

Maloney, M., and R. McCormick, "A Positive Theory of Environmental Quality Regulation." Journal of Law and Economics 25 (April 1982), 99-123.

Maloney, M., R. McCormick, and M. Tollison. “Achieving Cartel Profits Through Unionization." Southern Economic Journal 46 (October 1979), 628-634.

Merrifield, David E., and Richard W. Hayes. "The Adjustment of Product and Factor Markets: An Application to the Pacific Northwest Forest Products Industry." American Journal of Agricultural Economics 66 (1) (February 1984), 79-87. Mitchell, Merwin W., and Joe A. Stone. "Union Effects on Productivity: Evidence from Western U.S. Sawmills." Industrial and Labor Relations Review 46 (1) (October 1992), 135-145.

Montgomery, Claire, and Gardner M. Brown, Jr. "Economics of Species Preservation: The Spotted Owl Case." Contemporary Policy Issues 10 (2) (April 1992), 1-12.

Murray, Brian C., and David N. Wear. "Federal Timber Restrictions and Interregional Arbitrage in U. S. Lumber." Land Economics 74 (1) (February 1998), 76-91.

Rubin, Jonathan, Gloria Helfand, and John Loomis. "A Benefit-Cost Analysis of the Northern Spotted Owl." Journal of Forestry 89 (1991), 25-30.

Williamson, Oliver. "Wage Rates as a Barrier to Entry: The Pennington Case in Perspective." Quarterly Journal of Economics 82 (February 1968), 85-116. 
